\title{
DIFUSÃO DE SÍMBOLOS DE ÓDIO: MODELOS JURÍDICOS DE CRIMINALIZAÇÃO
}

\author{
DISSEMINATION OF HATE SYMBOLS: LEGAL MODELS OF CRIMINALIZATION
}

Doutorado em Direito pela Instituição Toledo de Ensino de Bauru (2017), Mestrado em Direito pelo Centro Universitário Eurípedes de Marília (2014), Especialização em Direito Penal e Direito Processual Penal pela Faculdade de Direito Damásio de Jesus (2014), Graduação em Direito pela Instituição Toledo de Ensino (2012).

\section{Resumo}

Precedentes importantes na jurisprudência internacional apontam para a possibilidade de restringir a difusão de símbolos controversos em decorrência do discurso de ódio, principalmente aqueles relacionados ao nacional-socialismo e neonazismo. No Brasil, a Lei 7.716/89 criminaliza a difusão da suástica para fins de divulgação do nazismo. Todavia, esta norma constitui um instrumento pouco eficaz na realização de seus propósitos. O presente trabalho pretende traçar investigação acerca da criminalização dos símbolos de ódio com base no tratamento penal sobre a divulgação do nazismo. A metodologia consiste na análise da literatura jurídica e jurisprudencial relacionada aos tipos penais que coíbem a simbologia discriminatória. As conclusões apontam para a adoção de um modelo de criminalização ampliativo, contextual e finalístico, no sentido de promover a limitação pontual dos símbolos de ódio, considerando a possibilidade de diferentes aproximações valorativas do espectador e a intercambialidade dos emblemas discriminatórios.

Palavras-chave: Liberdade de Expressão; Modelos de Criminalização; Nazismo; Símbolos de Ódio; Tolerância.

\begin{abstract}
Important precedents in international jurisprudence point to the possibility of restricting the diffusion of controversial symbols as a result of the hate speech, notably those related to National Socialism and Neo-Nazism. In Brazil, Law 7.716/89 criminalizes the dissemination of the swastika for Nazi disclosure purposes. However, this rule is an ineffective instrument in the fulfillment of its purposes. The present work intends to trace research on the criminalization of the symbols of hate based on the criminal treatment on the nazi dissemination. The methodology consists of the analysis of the legal literature and jurisprudence related to the criminal types that curb the discriminatory symbology. The conclusions point to the adoption of an amplifying, contextual and finalistic model of criminalization, in
\end{abstract}


order to promote the punctual limitation of the symbols of hatred, considering the possibility of different values approaches of the spectator and the interchangeability of the hatred emblems.

Keywords: Freedom of expression; Criminalization Models; Nazism; Symbols of Hate; Tolerance.

\section{CONSIDERAÇÕES INICIAIS}

A difusão de símbolos configura uma das expressões do discurso de intolerância com influxos mais importantes na seara jurídica. Se, ao mesmo tempo, os símbolos servem para representar ou apostatar opiniões, doutrinas ou ideias, eles também perfazem um dos mais eficazes meios na difusão de mensagens. Boa parte dos países na atualidade adota algum modelo de criminalização sobre a exibição de símbolos percebidos como discriminatórios ou acintosos às sensibilidades de minorias. Tanto o nazismo, quanto o fascismo, neonazismo e Ku Klux klan representam movimentos históricos dotados de rico acervo iconográfico que acaba sendo incorporado como um dos veículos mais eficazes na disseminação do preconceito.

O argumento mais convincente para criminalizar delitos específicos relacionados a crimes totalitários relaciona-se com a necessidade de proteger a dignidade e igualdade das vítimas. No que diz respeito ao uso de símbolos, existe uma tensão notável entre o direito à liberdade de expressão e as restrições baseadas em um legado histórico característico. Nessa linha, a criminalização desses símbolos gráficos e outras formas de expressão relacionadas constitui um desafio à medida em que é demandada a articulação de diversos fatores jurídicos colidentes.

Um dos exemplos mais característicos destes entraves diz respeito à suástica nazista e outros emblemas próprios do nacional-socialismo. Existem modelos penais que proíbem seu uso em qualquer contexto de apologia, a exemplo do brasileiro, enquanto outros permitem sua divulgação ainda que em conjuntura discriminatória, como no caso norte-americano. Para além disso, a atribuição objetiva do conteúdo axiológico de tais símbolos faz com que exista vedação à divulgação de conteúdo em si, desconsiderando outros critérios como o contexto da difusão.

Logo, surgem questionamentos de ordem teórica que levam o intérprete a questionar a licitude na exibição de símbolos nazistas dentro dos mais variados 
contextos (promocionais, apologéticos, acadêmicos, artísticos). Tal possibilidade estará sempre vinculada ao modelo de criminalização adotado pelo respectivo país que, com maior ou menor sucesso, vêm coibindo a proliferação do ódio no âmbito social.

Este artigo visa à compreensão dos elementos teóricos que compõem os modelos penais de criminalização de símbolos de ódio, apontando as soluções jurídicas mais adequadas para a construção legislativa no Brasil. De forma subjacente, objetiva-se aclarar ao leitor os principais modelos e suas premissas teóricas, apontando seus méritos e falhas, além da compreensão jusfilosófica da tolerância nas condutas deste jaez.

Diante deste cenário, estabelece-se a problemática da presente pesquisa, no sentido de aferir a congruência das técnicas e mecanismos jurídicos de combate a disseminação dos símbolos de ódio, formulando-se as seguintes questões de pesquisa: I) Quais são os tipos de discriminação odiosa formatadas pela divulgação de símbolos? II) Como construir um modelo de criminalização adequado para otimizar o Direito neste realidade?

A construção da pesquisa é realizada com base na análise crítica da legislação e dos precedentes relacionados aos influxos penais na difusão de símbolos de ódio e os respectivos mecanismos jurídicos de proteção, utilizando-se do método dedutivo e da pesquisa no campo histórico.

A proposta deste texto consiste em discutir, na primeira parte, a abordagem do critério da seletividade da tolerância com relação aos símbolos de ódio; na segunda parte, parte-se da compreensão do paradigma norte-americano e os precedentes da Suprema Corte na criminalização do hate speech envolvendo emblemas de grupos de ódio. Na terceira seção, o estudo volta-se para a crítica em torno da adoção de um critério ampliativo no conteúdo de símbolos e a maleabilidade de tipificação destes. Por fim, na quarta parte se discutirá a impropriedade da valoração objetiva dos símbolos de ódio, sob o argumento da existência de apreciações axiológicas distintas na exibição destes.

\section{SELETIVIDADE E O PARADOXO DA INTOLERÂNCIA}

Uma das questões mais importantes que ganha corpo no debate relacionado à liberdade de expressão seria a possibilidade de limitar juridicamente modulações do 
discurso de ódio, como a apologia a regimes totalitários ou a exibição pública de seus símbolos ou traços de identificação característicos (hinos, saudações, uniformes, imagem de seus líderes). Cabe chamar a atenção para o fato da existência de padrões de enfrentamento bastante distintos entre si no cenário internacional. Enquanto em algumas nações, como nos Estados Unidos, fixam-se limites contingentes à liberdade de expressão voltados para o "estilo do discurso", em outras, como no Brasil e Alemanha, tais limitações são conteudísticas - referem-se especificamente ao teor da mensagem ou simbologia propalada.

Um primeiro aspecto na construção do núcleo argumentativo desenvolvido no presente trabalho diz respeito ao paradoxo da tolerância, ou seja, obrigatoriedade de se tolerar aqueles que não nos toleram. O conceito de tolerância assume papel central no contexto político atual, posto que ambivalente. Sua ressignificação moderna ganha acentuado valor ideológico na medida em que se tenta adjetivar a própria posição como tolerante e a dos demais como intolerante ou, no mínimo, inadequada. Esses limites tão controversos suscitam dúvidas importantes como até que ponto os cidadãos devem fazer uso do ordenamento jurídico como um meio de se reforçar e defender os limites de tolerância - em outras palavras, o quão tolerante deve ser a lei? (FORST, 2009)

É o que Karl Popper (1945) denomina de "paradoxo da tolerância". A tolerância absoluta, mesmo para com os intolerantes, acabaria por eventualmente eliminar os condescendentes. O critério sugerido por Popper e referendado por Forst (2009) seria a razoabilidade, ou seja, o encontro de um ponto médio entre a tolerância leniente e a censura institucionalizada. Não se deve tolerar absolutamente tudo, ao passo que também não é adequado renunciar a qualquer forma de tolerância para com aqueles que não a respeitam.

Comte-Sponville (2009, p. 85) questiona: "Se devemos tolerar a Bíblia, por que não Mein Kampf'? E, se toleramos Mein Kampf, por que não o racismo, a tortura, os campos de concentração?" Uma tolerância universal implica no esquecimento das vítimas. Tolerar o sofrimento alheio e o horror resulta em uma injusta indiferença. Levada ao extremo, a tolerância acabaria por negar a si própria. Parece contraditório estender a liberdade de expressão a extremistas que, no bojo de sua agenda odiosa,

\footnotetext{
1 Obra escrita por Adolf Hitler em 1925 que expõe a súmula da ideologia nazista e claras referências ao arianismo e ao antissemitismo.
} 
reprimem sistematicamente a voz daqueles de quem discordam (ROSENFELD, 1987).

O problema da tolerância surge com mais frequência nas questões de opinião envolvendo tópicos com maior polarização dentro da sociedade. Política, religião, ações promocionais a certos grupos vulneráveis ou minorias, crenças pessoais acerca de agendas públicas de enfrentamento a criminalidade ou drogas e nacionalismo são só alguns exemplos nos quais o discurso passional acaba por se exuberar e, frequentemente, assimila-se uma posição de ódio ou supressão do dissenso.

Contextualizar a definição de tolerância em um contexto juridicamente aplicável é uma tarefa árdua. A liberdade de expressão não é peremptória e absoluta, havendo restrições impostas pelo próprio ordenamento jurídico; no caso do Brasil, barreiras normativas são indicadas pelo constituinte (como no caso dos mandados constitucionais de criminalização do racismo e de todas as discriminações atentatórias às liberdades fundamentais - art 5ํ, XLII e XLI), sem homiziar as que resultem de colisão com outros direitos fundamentais presentes no sistema constitucional.

Ao mesmo tempo, esse mesmo conceito de tolerância não é estanque. A forma como os limites de tolerância são historicamente traçados e as linhas divisórias entre o intolerável/tolerável são espaços nebulosos que demandam desconfiança crítica. Um esforço contínuo deve ser estabelecido para questionar a origem desses limites, contra quem eles são impostos e por quais motivações. De certo que, permutavelmente, nichos de poder alçam o poder e conseguem a precedência de suas demandas frente outras de igual relevância. Logo, existe sempre a possibilidade real de que a concretização jurídica de tolerância/intolerância tenha uma relevante carga político-ideológica que desconsidere o contexto democrático - invoca-se o argumento da intolerância de forma seletiva.

Só assim pode a crítica a uma (possível) ação contra a 'intolerância' ser ela mesma mais do que apenas outra forma de 'intolerância'.

Tolerância é o que eu chamo de um conceito normativamente dependente, o qual, para que tenha um determinado conteúdo (e limites especificáveis), carece de recursos normativos adicionais que não sejam dependentes nesse mesmo sentido. Tolerância não é, portanto, contrariamente a uma visão comum, ela mesma um valor, mas, em vez disso, uma atitude requerida por outros valores ou princípios.

A história da tolerância demonstra que ela não tem sido alcançada com muita frequência, já que as ideias de ordem política e moralidade que foram até então utilizadas para o propósito eram excessivamente particularistas e, em especial, enviesada [...] (FORST, 2009)

No campo do Direito a tolerância exige uma interpretação progressiva e 
contextual sem, contudo, olvidar seu caráter ubíquo - aplicando-se tanto para os tipos de discriminação com maior reprovabilidade social, quanto para aqueles que, pela conjectura política de poder, têm menor proeminência no cenário jurídico e reduzida condenação moral. Essa seletividade na intolerância deve ser evitada a todo custo, sob pena de estar-se criando um index proibitorium de ideologias e ideias consideradas peremptoriamente como danosas a convivência social pacífica.

A tolerância apresenta-se como um conceito normativamente dependente, carecendo de recursos normativos adicionais autossuficientes (e, portanto, que não sejam novamente dependentes nesse mesmo sentido) para que adquira um determinado conteúdo e limites especificáveis. Não é possível solucionar o paradoxo da tolerância por um denominador comum, por meio de uma perspectiva democrática que possui valor em si mesma, mas através de instrumentos jurídicos que demanda outros valores ou princípios imanentes do Direito. Para evitar a arbitrariedades, a adjetivação de determinado discurso como intolerante deve ser sempre interpretada à luz de um sistema constitucional de direitos fundamentais que garanta a todos (e não apenas a algumas minorias) a efetiva proteção no pleno exercício da igualdade. (FORST, 2009)

As proposições dialéticas da tolerância demonstram a existência e prática de liberdades em pré-condições que possibilitam a exibição de determinada simbologia transcenda o viés objetivo e adentre o campo motivacional. Em geral, a função e o valor da tolerância dependerão da concepção jurídica dada à igualdade na sociedade em que a tolerância é praticada. Seus limites e alcance não podem ser definidos em termos na respectiva sociedade, de forma que a tolerância releva-se como valor de isenção cuja finalidade é funcionalizada ao sistema constitucional de direitos fundamentais - determinando e definindo por vias institucionais os parâmetros de compatibilidade desta com o direito à igualdade.

Essas linhas de tolerância são fixadas por critérios implícitos e explícitos nas limitações judiciais, pelos costumes e pela legislação e sobrescritos em critérios adotados pelos modelos de criminalização - susceptibilidade à violência, perigo claro e iminente, ameaça à segurança pública, etc (MARCUSE, 2007). Tal problemática ganha conotação específica quando se está a tratar da exibição iconográfica relacionada com regimes totalitários e grupos de ódio e sua simbologia característica. Portanto, resta a questão de como estabelecer critérios adequados para conjugar a liberdade de expressão e a necessidade de a sociedade tolerar manifestações que 
desagradem a maioria, com o ideal de proteção das sensibilidades dos grupos minoritários que se sintam ofendidos com a propalação.

\section{PARADIGMA NORTE-AMERICANO: PRECEDENTES DO DISCURSO DE ÓDIO E A EXIBIÇÃO PÚBLICA DE SÍMBOLOS}

O paradigma constitucional norte-americano coloca 0 sistema de criminalização dos Estados Unidos como um dos mais liberais no mundo relacionado ao hate speech. Um dos avanços mais notórios introduzidos pela jurisprudência americana foi clarificar que nem toda expressão de ódio possui idêntica potencialidade vulnerante. Enquanto o discurso não tiver a potencialidade de provocar reações violentas ele será considerado lícito por mais ignóbil ou reprovável que seja o seu conteúdo. Isso ocorre porque o foco da proteção jurídica é resguardar a ordem e a segurança pública².

O sistema de proteção baseado no conteúdo da Primeira Emenda confere tutela diferencial às variadas espécies de discursos propalados. Enquanto para algumas a proteção é menos intensa, em outras áreas a garantia constitucional recebe amplo reforço, como no caso do discurso político ou ideológico. A discordância relativa ao ponto de vista do interlocutor é vista com inúmeras ressalvas, de modo que este tipo de expressão apenas poderá ser limitado no estilo de sua apresentação (tempo, lugar e modo ${ }^{3}$ ), mas não em seu conteúdo. Com efeito, os precedentes Chaplinsky v. New Hampshire ${ }^{4}$, National Socialist Party of America v. Village of Skokie ${ }^{5}$ e Colin v. Smith 6 fixaram aquilo que a literatura jurídica viria a designar de fighting words (palavras de combate), uma expressão que por sua natureza teria a capacidade de dar gênese à reação virulenta e violenta da plateia ou grupo opositor à mensagem.

A Suprema Corte dos Estados Unidos identifica como constitucional a formação de partidos, associações ou grupos que, de maneira explícita ou implícita, adotem a agenda, ideário ou simbologia de regimes totalitários. Para além disso, permite-se que a liberdade associativa e de expressão seja funcionalizada para o fomento do ódio e expressada publicamente (em passeatas, manifestações,

\footnotetext{
2 Importante fazer a ressalva de que determinados tópicos encontram-se fora do âmbito da proteção jurídica da liberdade de expressão: pedofilia, obscenidade, palavras de apologia à desordem.

${ }^{3}$ Cox v. New Hampshire, 312 U.S. 569 (1941); Ward v. Rock Against Racism, 491 U.S. 781 (1989)

${ }^{4}$ Chaplinsky v. New Hampshire, 315 U.S. 568 (1942)

${ }^{5}$ National Socialist Party of America v. Village of Skokie, 432 U.S. 43 (1977)

${ }^{6}$ Collin v. Smith, 578 F.2d 1197 (1978)
} 
publicações), desde que respeitados os limites da ausência das fighting words e de perigo atual e iminente (clear and present danger`) no teor do discurso de ódio.

Um dos casos mais importantes na jurisprudência americana com relação à exibição de símbolos de ódio ocorreu na cidade de Skokie, Estado de Illinois. O Partido Nazista da América organizou uma manifestação política no município em razão da predominância judaica de sua população. A liderança nacional-socialista recorreu para a Suprema Corte visando que fossem declaradas inconstitucionais medidas administrativas impostas pelas autoridades locais que obstariam a manifestação. A Corte decidiu que o uso dos estandartes característicos do nazismo constitui forma simbólica de expressão e, portanto, estariam acobertados pela Primeira Emenda; por unanimidade, sedimentou-se que a suástica não teria em si um valor próprio capaz de atribuir a categoria de fighting words em seu uso.

A existência de legislação que criminalize a disseminação de símbolos não cria suficiente dissuasão por si mesma, demandando um constante redirecionamento jurisprudencial a fim de refletir os crimes de ódio por um prisma mais abrangente. Destarte, os legisladores enfocam sua produção normativa em torno da "demanda existente". A criminalização do ódio no sistema americano tornou-se restrita essencialmente por motivações simbólicas, uma vez que os poucos tipos penais existentes frequentemente são taxados de desnecessários, injustos e inconstitucionais. (JACOBS; POTTER, 2000)

Diante deste cenário, cumpre responder: quais expressões simbólicas ou símbolos merecem uma criminalização específica e quais devem ser albergados pela liberdade de expressão? Jacobs e Potter (2000) acreditam que sistematizar uma lista de símbolos que acionariam uma severidade maior do sistema penal é demasiadamente problemático.

A divulgação da indumentária característica da Ku Klux Klan, da camiseta com a imagem de líder nazista ou de cartazes que exibem os momentos finais das vítimas do Holocausto desencadeiam consequentes mais graves do que palavras de ordem como "mandem os Democratas para o inferno" ou "abaixo a Igreja" comumente ventiladas em manifestações públicas? $O$ cotejo na abordagem jurídica de precedentes como Brandenburg v. Ohio e Snyder v. Phelps ${ }^{8}$, já provaram que a

\footnotetext{
${ }^{7}$ Critério fixado no case Brandenburg v. Ohio, 395 U.S. 444 (1969).

8 Snyder v. Phelps, 562 U.S. 443 (2011)
} 
Suprema Corte não está disposta a realizar este tipo de diferenciação.

Criar uma lista negra de palavras, expressões e símbolos sujos de "ódio" que garantam uma punição aprimorada seria uma tarefa demasiadamente subjetiva, eivada de premissas políticas e sem um ponto de vista neutro. Em última instância, isso equivaleria a escolher e escolher símbolos que o legislador considera ofensivos. Este raciocínio pode violar a Primeira Emenda, como no precedente Texas $v$. Johnson, o caso de queima de bandeira. Nele, o réu foi condenado por queimar uma bandeira em uma manifestação política em violação de um estatuto do Texas que proíbe incendiar bandeira americana. A Suprema Corte considerou a lei inconstitucional com fundamento na Primeira Emenda. (JACOBS; POTTER, 2000 , p. 85$)^{9}$

A criação de critérios ampliativos para a criminalização de símbolos, atribuindo-se natureza de veículo do ódio, pode reforçar a ideia de tolerância, desde que associado com normas descriminantes que limites a epistemologia da proibição, a exemplo da permissão para veicular símbolos controversos em contextos socialmente positivos (finalidades artísticas, acadêmicas ou de pesquisa).

No ano de 1992, a Suprema Corte manifestou-se favoravelmente ao pedido de inconstitucionalidade de lei criminal editada pelo Estado de Minnesota que sancionava a inserção em propriedade pública símbolo ou objeto como a suástica ou a cruz em fogo com o objetivo de causar raiva, medo ou ressentimento em razão da raça, cor, crença, religião ou gênero ${ }^{10}$. No leading case R.A.V. v. City of St. Paull11 reverteu-se a condenação criminal contra um grupo de jovens de incendiaram crucifixos no jardim de uma família (simbologia típica da Klan) para finalidades discriminatórias.

O modelo democrático americano, mesmo diante dos inúmeros relatos de vilipêndios discriminatórios mediante o uso da simbologia de doutrinas de ódio, não ofereceu soluções para os problemas desencadeados por um óbice fundamental: o irrestrito culto à liberdade de expressão. Esse espaço de excessiva autonomia permite que o indivíduo defenda suas preferências, seu estilo de vida e, principalmente, suas

\footnotetext{
${ }^{9}$ Original em ingles: "Creating a blacklist of dirty "hate-ist" words, expressions and symbols that warrant enhanced punishment would be a very subjective politically loaded and nonviewpoint-neutral task. Ultimatle, it would amount to picking and choosing symbols that lawmaker finds offensive. This might violate the First Amendment under Texas v. Johnson, the flag burning case. In Johnson, the defendant was convicted for burning a flag at a political rally in violation of a Texas statute prohibiting burning of the American flag. The Supreme Court held the law to be unconstitucional under the First Amendment." 10505 U.S. 379 - Whoever places on public or private property, a symbol, object, appellation, characterization or graffiti, including, but not limited to, a burning cross or Nazi swastika, which one knows or has reasonable grounds to know arouses anger, alarm or resentment in others on the basis of race, color, creed, religion or gender commits disorderly conduct and shall be guilty of a misdemeanor. 11 R.A.V. v. City of St. Paul. 505 U.S. 377, n. 90-7675 (1992).
} 
convicções racistas em um panorama aparentemente neutro. A tolerância absoluta, externada sem critérios e limitações desemboca na supressão do outro, não há espaço para as diferenças.

Não obstante os precedentes das cortes americanas sejam paradigmáticos ao demonstrar a necessidade da fixação de critérios mínimos para a restrição da iconografia, ao menos nos casos mais extremados, acabou-se por demonstrar algo ainda mais importante: a ideia de que a sociedade deve ser rígida cultora da liberdade de expressão racional e zelar para não aderir aos velhos argumentos de censura. Para os casos limítrofes, nos quais inexista clara delimitação da finalidade discriminatória e cujo estilo de apresentação não seja evidentemente acintoso e a exibição ocorra dentro de contexto razoável, o judiciário deverá abandonar a dialética da legalidade/criminalização e adotar o raciocínio da conveniência e oportunidade de tal exibição. Assim, a projeção da imagem de Adolf Hitler pode ser perfeitamente plausível dentro de certas circunstâncias, mas será inoportuna, por exemplo, se realizada dentro de uma sinagoga judaica.

\section{RESSIGNIFICAÇÃO DO CONTEÚDO DE SÍMBOLOS: ANÁLISE À LUZ DA EXPERIÊNCIA DE CRIMINALIZAÇÃO DO NAZISMO}

Em 23 de maio de 2016, foi apresentado ao plenário da Câmara dos Deputados o Projeto de Lei 5358/2016 que, em síntese, altera a redação da Lei 7.716/1989 (Lei de combate à discriminação) e da Lei 13.260 (Lei do terrorismo) para criminalizar a apologia ao comunismo. A modificação incidiria nos dispositivos do artigo $1^{\circ}, 20$ caput e $\S 1^{\circ}$ da Lei 7.716 , que passaria a vigorar nos seguintes termos:

\footnotetext{
Art. 10 Serão punidos, na forma desta Lei, os crimes resultantes de discriminação ou preconceito de raça, cor, etnia, religião, procedência nacional ou de fomento ao embate de classes sociais

Art. 20. Praticar, induzir ou incitar a discriminação ou preconceito de raça, cor, etnia, religião, procedência nacional ou fomentar o embate de classes sociais.

$\S 1^{\circ}$ Fabricar, comercializar, distribuir ou veicular símbolos, emblemas, ornamentos, distintivos ou propaganda que utilizem a cruz suástica ou gamada, a foice e o martelo ou quaisquer outros meios para fins de divulgação favorável ao nazismo ou ao comunismo. ${ }^{12}$ (g. n.)
}

\footnotetext{
${ }^{12}$ Art. 1. Serão punidos, na forma desta Lei, os crimes resultantes de discriminação ou preconceito de raça, cor, etnia, religião, procedência nacional.

Art. 20. Praticar, induzir ou incitar a discriminação ou preconceito de raça, cor, etnia, religião ou procedência nacional.

$\S 1^{\circ}$ Fabricar, comercializar, distribuir ou veicular símbolos, emblemas, ornamentos, distintivos ou
} 
$\mathrm{Na}$ justificação anexa ao referido projeto sustenta-se a perniciosidade de um contínuo fomente subliminar ou explícito do embate entre classes sociais que abriga como motivação subjacente a apologia à doutrina que exterminou mais de 100 milhões de pessoas nos mais distintos programas genocidas instaurados pelos regimes comunistas no mundo. Não obstante a proposta principal de criminalização da apologia ao comunismo, importa aqui a análise das possíveis alterações secundárias no modelo sancionatório de divulgação do nazismo. Contudo, inicialmente é relevante explicitar o atual quadro jurídico da legislação em debate.

A norma atualmente em vigor (art. 20, $§ 1^{\circ}$, Lei 7.716/89) insere condutas específicas de propalação (fabricar, comercializar, distribuir ou veicular) vinculadas exclusivamente a objetos que contenham a suástica (símbolos, emblemas, ornamentos, distintivos ou propaganda que utilizem a cruz suástica ou gamada) na medida em que o agente possua um desiderato específico para divulgar a doutrina nacional-socialista (para fins de divulgação do nazismo).

A síntese do raciocínio motriz para a aplicação da referida norma incriminadora é a seguinte: a) Identifica-se o regime nazista como um dos mais nefastos na perseguição de minorias e na institucionalização do arquétipo de uma raça superior; b) Atribui-se uma vinculação necessária entre este e seu símbolo mais notório, a suástica; c) Presume-se a potencialidade nociva na divulgação da doutrina nazista e seus referidos estandartes; d) Para a proteção das sensibilidades dos cidadãos, o Estado se movimenta para estabelecer regimes de proibição, como a criação de tipos de perigo abstrato (art. 20, $§ 1^{\circ}$ ).

Baseado nessas quatro características centrais, a tentativa de criminalização de apologia ao regime totalitarista de Hitler aponta para problemas importantes, mas parte de premissas equivocadas.

A primeira delas consiste na vinculação entre a suástica e o nazismo: a suástica era e continua sendo utilizada por inúmeras culturas, com significações exponencialmente distintas da significação atribuída ao estandarte nacional-socialista (MARCHERI, 2014). Seus primeiros registros remontam para o período paleolítico na região do Irã, mas sua representação gráfica pode ser encontrada na antiga Esparta, nos povos indígenas americanos, na China, Índia e também na mitologia nórdica

propaganda que utilizem a cruz suástica ou gamada, para fins de divulgação do nazismo. 
(PAVITT; PAVITT, 1992).

Afinal, se a penalização concentra-se exclusivamente na suástica, o que dizer dos inúmeros contextos em que esse mesmo emblema é divulgado por outras culturas? Por conseguinte, qual a eficácia em se criminalizar a promoção do nacionalsocialismo exclusivamente via tal símbolo, ignorando, por exemplo, a veiculação da imagem de Adolf Hitler e das infindáveis representações gráficas criadas pelo nazismo, como as insígnias da SS (Schutzstaffel) ${ }^{13}$ ou da águia imperial (Reichsadler)? (FIJALKOWSKI, 2014)

Santos (2010, p. 130) relata o contrassenso da norma em comento:

\begin{abstract}
Procurou-se com tal norma promover a justa repressão - em defesa da sociedade democrática - a algumas formas de divulgação do nazismo, porém, mais uma vez, o elaborador do teto não obrou com felicidade, limitando seu alcance, já que a realização de ampla campanha de divulgação do nazismo pela televisão, por exemplo, usando até mesmo a águia nazista e o rosto de Adolf Hitler (mas não a suástica), não poderá ser punida na forma deste $\S^{\circ}[\ldots]$.
\end{abstract}

A segunda premissa falha consiste na ilação da potencialidade nociva do nacional-socialismo: essa tentativa de se destruir radicalmente qualquer expressão que potencialmente viole sensibilidades de grupos desconfortáveis com a matéria acaba por homiziar outros direitos fundamentais presentes, como a liberdade de expressão e de pesquisa. Fato perceptível na ênfase dada ao tipo penal, acaba-se por criminalizar de maneira resoluta qualquer forma de propalação do nazismo, ainda que em contextos mais favoráveis.

Finalmente, e com maior destaque, o equívoco na atribuição de um valor objetivo e uma interpretação meramente restritiva à simbologia: símbolos não perfazem meras representações gráficas de valor imaterial ou objeto material. De igual maneira, a esses símbolos não se pode conferir um valor em si mesmo, cada indivíduo (sujeitos dotados de capacidade crítica) podem ter diferentes apreciações valorativas sobre os símbolos.

Mencionando novamente o Projeto de Lei 5358/2016, as alterações propostas acabam por corrigir parte das vulnerabilidades anteriormente apontadas. A composição atual dos tipos penais de proibição de símbolos faz com que o Brasil seja adotante de um sistema de criminalização de tipificação nominada ou específica. Ela

\footnotetext{
13 Tropa militar de elite nacional-socialista, conhecida por adotar como valor institucional o rígido culto e obediência ao Führer, representou o apanágio dos valores arianos.
} 
consiste na menção textual e restritiva dos emblemas proibidos pela norma penal e o arrolamento das doutrinas ou movimentos aos quais se associam tais insígnias. Semelhantemente, a Hungria possui norma incriminadora ${ }^{14}$ que contempla 0 arrolamento dos símbolos cuja exibição é proibida por lei. O emblema rúnico da SS, o pavilhão do partido nazista húngaro (cruz de flechas), a bandeira Árpád (estandarte oficial de grupo político de extrema-direita), além dos distintivos típicos adotados pelo comunismo e o nazismo são criminalizados pela lei.

Note-se que o Projeto de Lei 5358/2016 foi construído no mesmo traçado da legislação penal húngara - criminalizando a exibição pública da estrela vermelha de cinco pontas, o martelo e a foice, além da suástica. Contudo, a criminalização estrangeira realiza um arrolamento não restritivo de emblemas, possibilitando o aporte de outros que façam parte da simbologia dos regimes totalitários sancionados; no caso da atual Lei 7.716/1989, a construção do tipo penal fechado não abre margem para que outros símbolos que não a suástica sejam abrigados pela norma.

Tal noção constitui um cenário que irá respaldar a invisibilização de expressões odiosas significantemente equânimes a aquelas já identificadas no quadro jurídico atual. Resulta problemática a utilização desse padrão incriminador que deixa de perceber outras representações gráficas ou mesmo manifestações simbólicas diversas como expressões claras desses movimentos de ódio. Analiticamente, nesses casos defende-se a construção de generalizações pontuais e a abertura dos tipos penais para punir a discriminação odiosa em sua plenitude de formas.

Como os símbolos tradicionais do nazismo foram proibidos em vários países na Europa, os grupos de ódio acabaram adaptando suas manifestações por meio do uso de outros símbolos menos difundidos, a exemplo das runas célticas, os números "88" e "14"15 e a caveira Totenkopf16.

14 "Seção 269/B (Código Penal) - Uso de símbolos do despotismo

(1) Aquele que: a) distribuir; b) veicular em mídia de massa; c) exibir publicamente; uma suástica, símbolo da "SS", cruz de flechas, foice e o martelo, estrela vermelha de cinco pontas, ou um símbolo que represente estes, se não constituir delito mais grave, comete uma contravenção. Pena - Multa.

(2) Aquele que pratica a conduta descrita na subseção (1) com a finalidade de divulgar o conhecimento, educação, ciência ou arte, ou com o propósito de informar sobre os eventos históricos ou atuais, não será punido.

(3) As disposições das subseções (1) e (2) não se aplicam aos símbolos oficiais do Estado em vigor." (MARCHERI, 2015)

15 O 88 é uma referência a oitava letra do alfabeto "H", que em dupla forma a abreviação da saudação nazista "Heil Hitler". O numeral 14 é uma alusão ao mote do teórico neonazista David Lane, conhecido como as quatorze palavras "Devemos assegurar a existência de nosso povo e um futuro para as crianças brancas"

16 Totenkopf é o termo alemão que significa "cabeça da morte". Primordialmente é associado ao 
Não obstante o esforço legislativo em coibir manifestações discriminatórias em que exista o uso de símbolos, nenhuma lista finita conseguirá contemplar com satisfatoriedade toda gama de figuras ou expressões podendo significar o ódio. Sua intercambialidade é somada ao fato de que, frequentemente, seus traços característicos são adulterados na tentativa de ilidir a criminalização - invertem-se cores, traços, sentidos e delineamentos para formar um novo símbolo que faz alusão ao tradicional ${ }^{17}$.

Assim como as doutrinas racistas, os símbolos nascem e tombam, sucedemse uns aos outros. Para expressar a mesma ideia, renová-la ou transformála, os símbolos são trocados com muita facilidade, dependendo sempre do contexto de sua aparição e de seu ocaso. (SILVEIRA, 2007, p. 226)

O Código Penal alemão, por exemplo, utiliza o padrão de criminalização indireta, não indicando nominalmente os grupos ou símbolos proibidos (com exceção da menção expressa ao nacional-socialismo). A Seção $86-\mathrm{A}^{18}$ contém 0 tipo incriminador referente ao "Uso dos Símbolos das Organizações Inconstitucionais", contemplando a divulgação da simbologia nazista, neonazista e de outros grupos de

nazismo pelo seu uso proeminente nas tropas SS, mais especificamente no $3^{\circ}$ Batalhão da Waffen-SS, que foi batizado com o mesmo nome de seu estandarte.

${ }^{17}$ A legislação criminal alemã (§86-a) acertadamente determina a criminalização dos símbolos dublês que intencionalmente se assemelhem aos banidos (Den in Satz 1GB Kennzeichen stehen wie gleich, die Seiten zum Verwechseln sind sind). Já a legislação criminal federal americana, conhecida como U.S.C., impõe pena para aquele que adulterar emblema ou bandeira oficial dos Estados Unidos com fins discriminatórios ( $4^{\circ}$ U.S.C.), como a inserção da suástica ou da imagem de líder nazista no pavilhão norte-americano (Any person who for exhibition or display, shall place or cause to be placed any word, figure, mark, picture, design, drawing, or any advertisement of any nature upon any flag, standard, colors, or ensign of the United States of America [...] shall be deemed guilty of a misdemeanor).

18 \$ 86a Verwenden von Kennzeichen verfassungswidriger Organisation

(1) Mit Freiheitsstrafe bis zu drei Jahren oder mit Geldtrafe wird bestraft, wer

1. im Inland Kennzeichen einer der in $\S 86$ Abs. 1 Nr. 1, 2 und 4 bezeichneten Parteien oder Vereinigungen Verbreiten oder öffentlich, in einer Versammlung oder in von ihm verbreiteten Schriften (§ 11 Abs. 3)

2. Gegenstände, die denartige Kennzeichen darstellen oder enthalten, zur Verbreitung oder Verwendung im Inland oder Ausland in der Nummer 1 bezeichneten Art und Weise herstellt, vorrätig hält, einführt oder ausführt.

(2) 1 Kennzeichen im Sinne des Absatzes 1 sind namentlich Fahnen, Abzeichen, Uniformstücke, Parolen und Grußformen. 2Den in Satz 1GB Kennzeichen stehen wie gleich, die Seiten zum Verwechseln sind sind.

Seção 86-A (Código Penal alemão) - Uso dos Símbolos das Organizações Inconstitucionais.

(1) Quem:

1. nacionalmente distribui ou utiliza publicamente, em reuniões ou textos ( $\$ 11$ subseção 3 ) divulgados por ele, símbolos de um dos partidos ou organizações indicadas no $\S 86$ subseção (1), n. 1, 2 e 4; ou 2. produz, estoca, objetos de importações ou exportações que retratem ou contenham tais símbolos para distribuição ou uso no mercado interno ou no exterior, na forma indicada no número 1.

Pena: Prisão de até três anos ou multa

(2) Símbolos, na acepção da subseção (1), serão em especial: bandeiras, insígnias, uniformes, slogans e as formas de saudação. Símbolos que são tão semelhantes que podem ser confundidos com aqueles nomeados no parágrafo $1^{\circ}$ devem ser considerados equivalentes. [...]".(DEUTSCHLAND, 2014) 
ódio - uma vez atribuída a natureza jurídica de organização infringente à ordem constitucional.

Com destaque, o parágrafo $2^{\circ}$ indica uma interpretação aberta do conceito de símbolos. Com densidade normativa superior, interpreta-se o valor linguístico de símbolo como uma representação convencional dissociada da materialização fotográfica. As bandeiras, insígnias, uniformes, slogans e as formas de saudação, sem prejuízo de outras manifestações, podem ser subsumidas ao tipo incriminador, já que atitudes discriminatórias são invocadas por símbolos nem sempre associados ao emento gráfico, como músicas antissemitas, a saudação 'Heil Hitler', a leitura pública do Mein Kampf ou mesmo a caracterização dos icônicos bigode e cabelo do Führer ${ }^{19}$.

Vale lembrar que símbolo diz respeito a representação de um conceito. Essa associação ocorre com a composição de signos ou registros que ganham sentido dentro de um contexto sociocultural. A demonstração ocorre por meio da associação entre a expressão representativa e a ideia representada. O símbolo é a representação de um conceito ou teorização: sua indicação geralmente ocorre por meio da composição de uma imagem ou signo, que é criada dentro de um contexto sociocultural, com a finalidade de representar algo. Por meio da analogia e associação, esta composição gráfica demonstra ou substitui outra coisa.

De acordo com a teoria da comunicação e semiótica, a identificação deste elemento representativo (que pode ser materializado em uma gravura, gesto, sonoridade, composição literária, etc) é feita por meio de uma "lógica crítica" que permite inferências de raciocínio como dedução ou indução (NICOLAU et al, 2010). Esta lógica possibilita ao receptor da mensagem identificar a substituição de sentido, por meio de uma "gramática especulativa": transformando palavras, imagens ou objetos sem nenhuma relação aparente entre si, em um símbolo convencionado pela cultura de uma sociedade. A significância da semiótica em um ideograma é contundente, pois a transmissão de conteúdo e de carga emocional ao receptor é mais célere se comparada ao discurso escrito ou falado (PIERCE, 1977).

Tais conclusões impactam diretamente a criminalização dos símbolos na

\footnotetext{
19 Stegbauer (2005, p. 178-179) complementa: "[...] there is no doubt that an impartial observer would recognize a sign as the symbol of a certain organization if it was formally created for that purpose. But most right-wing extremist symbols already existed in various contexts and were only adopted later. For example, the swastika of the NSDAP is an ancient sun sign; the double Sig rune of the Schutzstaffel (Protective Squadron [SS]) consists of Nordic characters. The association of signs with these banned organizations derives from their broad and permanent use in that special context which, in the public consciousness, definitely turns them into the symbols of the NSDAP"
} 
experiência brasileira. À luz da experiência alemã, a eficientização da proteção contra o discurso de ódio nesta seara depende do aprimoramento na legística de elaboração das normas incriminadoras, incorporando a ressignificação do conteúdo de símbolos por um viés ampliativo - que englobe qualquer tipo de gramática especulativa nesse sentido.

Realizou-se, em trabalhos anteriores, a crítica contrária ao uso do modelo de criminalização adotado pelo Brasil (PIERCE, 1977), opondo-se à criminalização nominativa de símbolos. Entretanto, o projeto de lei é salutar ao expor a seletividade na tutela do bem jurídico-penal vinculado à criminalização do discurso de ódio no Brasil. Não existe na literatura penal qualquer argumento razoável para que determinadas ofensas discriminatórias sejam criminalizadas em detrimento de outras.

Há uma predileção clara da lei por certas ideologias ou movimentos históricos de ódio, como o nazismo, muito embora inúmeras outras passem longe da atenção do legislador. Outrossim, nitidamente determinados símbolos são mais impactantes que outros na sociedade e por esse fato também recebem gradação diferencial em sua reprovabilidade. Por que criminalizar a suástica, mas não o uso dos emblemas e indumentária característica da Ku Klux Klan, os uniformes da Milizia Volontaria per la Sicurezza Nazionale (organização militar da Itália fascista) ou a simbologia de grupos supremacistas brancos?

Aqui o problema reside na ausência de aculturação para certas esferas simbológicas. A suástica é um dos símbolos mais representativos do antissemitismo no mundo, embora não esteja ligado unicamente à perseguição dos judeus - portanto, torna-se mais fácil e democrática sua projeção. Por outro lado, poucos são aqueles que conhecem as bandeiras germânicas imperiais tão representativas do governo prussiano de Otto von Bismarck no século XIX, igualmente conhecido por sua agenda antissemita.

Outro aspecto importante na criminalização dos símbolos de ódio diz respeito ao argumento da 'rampa escorregadia' (slippery slope). Basicamente refere-se a uma argumentação lógico-jurídica na qual se afirma que um primeiro passo em determinado sentido leva a uma cadeia de eventos relacionados, culminando em um relevante efeito negativo final. O núcleo do argumentativo corresponde a uma decisão especifica torna-se susceptível de resultar em consequências não intencionais, na medida em que as etapas sequencialmente tornam-se o novo paradigma ou ponto de partida para os demais avanços naquele mesma linha. 
Silveira (1997, p. 217) importa a lógica do slippery slope para o campo de criminalização de símbolos no Brasil:

Aqui na Vara de Uberaba, MG, decidi, em 1995, um caso interessante: a Câmara Municipal do Rio de Janeiro oficiou à $O A B$ daquela cidade protestando contra o uso da suástica estilizada como símbolo de um produto industrial (sabão), fabricado em Uberaba, cuja propaganda foi veiculada pela revista 'Contigo' (n. 744, de 21.12.1989, p.15). [...]. Através de sentença, determinei o arquivamento do inquérito policial, afirmando não vislumbrar a ocorrência de nenhum crime no caso. Deixei claro que, num país livre e democrático, ao indivíduo é facultado escolher os símbolos e hinos que melhor expressem suas convicções políticas, não podendo o Estado interferir no seu inafastável direito de livre manifestação do pensamento. Nossa Constituição não fez opção por uma determinada corrente filosófica ou política, desde que preservadas as cláusulas pétreas [...]. À luz desse entendimento não tenho dúvida em reputar inconstitucional o $\$ 1^{\circ}$ da Lei 9.459 de 13.5.1997, que incrimina com pena de reclusão de 2 a 5 anos e multa, o ato de 'fabricar, comercializar, distribuir ou veicular símbolos, emblemas, ornamentos, distintivos ou propaganda que utilizem a cruz suástica ou gamada para fins de divulgação do nazismo.' Embasa o raciocínio o fato de que o Estado que proíbe a suástica hoje, é o mesmo que proibirá no futuro, a cruz católica ou outro símbolo religioso ou político, como os dos partidos, por exemplo: a estrela do PT, a foice e o martelo do PC.

A iniciativa de criminalizar um símbolo de ódio não necessariamente leva à criminalização de todos. Todavia, isso não impede aprimoramentos quanto à ressignificação do conceito de símbolos para que se possa abarcar outras doutrinas e expressões que unicamente a representação gráfica do estandarte nazista.

Ao propor a adoção das elementares "quaisquer outros meios para fins de divulgação favorável do nazismo" o projeto de lei adota uma significação ampliativa dos símbolos e traz aprimoramentos interessantes para a criminalização no Brasil. Abre-se o leque de opções ao intérprete que poderá subsumir ao tipo penal do artigo 20, $\S 1^{\circ}$ qualquer representação (gráfica ou imaterial) do nacional-socialismo que seja funcionalizada para a discriminação de pessoas. Permite-se, por exemplo, a aplicação de reprimenda à aquele que realize saudação nazista em público ou exiba imagens das principais personalidades vinculadas ao nazismo.

Uma vez verificado que o uso da iconografia relacionada à grupos ou doutrinas de intolerância pode ser acintosa e demanda regulamentação, existem casos em que o emprego do símbolos gera conotação controversa. Dentro deste contexto, a ideia de atribuir peremptoriamente o caráter ilícito a determinados símbolos merece maior verticalização.

\section{VALORAÇÃO OBJETIVA DOS SÍMBOLOS DE ÓDIO}


A iniciativa de criminalizar um símbolo de ódio não necessariamente leva à criminalização de todos. Todavia, isso não impede aprimoramentos quanto à ressignificação do conceito de símbolos para que se possa abarcar outras doutrinas e expressões que unicamente a representação gráfica do estandarte nazista. Apartado do tópico anterior, se mostra fundamental discorrer acerca de outra vulnerabilidade no modelo de criminalização de simbologias: a valoração objetiva dos símbolos de ódio. Em síntese, o argumento exposto consiste na negativa de atribuir uma significação axiológica peremptória para cada expressão simbólica ligada a doutrina de ódio.

Em fevereiro de 2016, o juízo da 33ª Vara Criminal do Rio de Janeiro proferiu decisão cautelar determinando a proibição da venda do Mein Kampf que recentemente havia ingressado em domínio público ${ }^{20}$. Temendo um acréscimo vultoso na exploração comercial da obra e uma sequente onda de disseminação do ideário nacional-socialista, o judiciário exarou ordem penal prospectiva no sentido de que 0 conteúdo do livro, em última análise, configuraria o crime do artigo 20 , §2 da Lei 7.716/1989.

A vedação do comércio em tese geraria desconforto insuperável porquanto seu conteúdo ideológico violaria a igualdade (CF, art $\left.5^{\circ}\right)$ e afrontaria a dignidade e a prevalência dos direitos humanos (artigos $1^{\circ} \stackrel{\circ}{ }$, III e $4^{\circ} \stackrel{\circ}{ }$, VIII). Ademais, o próprio constituinte relegou tratamento austero a prática do racismo, que deve ser criminalizada de modo inafiançável, imprescritível e apenado com reclusão (art. 5º, XLII).

O valor historiográfico a ser atribuído ao texto hitleriano impõe a seguinte diferenciação: a abrangência de sua significação axiológica no campo da História perfaz atitude completamente distinta do uso efetivo para finalidades discriminatórias e, portanto, ilícitas (DELFINO, 2016). De fato, cada pessoa terá uma compreensão valorativa distinta sobre tais símbolos que lhe são apresentados, não sendo adequado firmar um determinismo axiológico, embora possam existir sinais de prevalência de sentido, de acordo com um contexto cultural específico (REALE, 2000).

Por consequência, a veiculação de uma única composição literária cuja relevância histórica é inestimável, já que releva a súmula da ideologia nazista, não merece a incidência das normas jurídico-penais sem que haja a imprescindível análise

${ }^{20}$ Medida Cautelar nº 0030603-92.2016.8.9.0001. Juiz Alberto Salomão Júnior. 02. fev. 2016. 
contextual de seu uso. A venda de obra nazista não deve, por si só, ser objeto de proibição.

Os limites contextuais como o tempo, lugar e modo são indicativos importantes sobre a tendência do uso de símbolo vinculado a ideologia odiosa. Será inoportuna, por exemplo, a leitura de trecho do livro no interior de uma sinagoga no exato instante do culto religioso, bem como dentro de um museu dedicado à memória das vítimas do Holocausto, ao passo que seu uso em uma aula de história ou no campo das artes indica a adequação volitiva.

Em 2004, a organização não governamental PETA Deutschland (People for the Ethical Treatment of Animals) lançou na Alemanha e na Áustria uma campanha publicitária, anteriormente divulgada nos Estados Unidos, intitulada "O Holocausto no Seu Prato". Esta consistia na exibição pública de painéis contendo imagens de judeus aprisionados ou mortos nos campos de concentração nacional-socialistas, ao lado de animais em cativeiro para a exploração comercial. A ideia central da campanha era estabelecer um cotejo direto entre o genocídio perpetrado pelos nazistas com a indústria de comércio de carne e derivados, adjetivada de "holocausto animal". A equivalência era explícita a plateia, o letreiro exibia com destaque a frase: "para os animais, todas as pessoas são nazistas"21.

O Tribunal Constitucional Alemão julgou favoravelmente as arguições constitucionais BvR 2266/04²2 e 2620/05²3, declarando que o conteúdo semântico na equivalência sugerida pela campanha publicitária era simbólico para o aviltamento a memória dos judeus ali retratados. O contexto tornava-se ainda mais desfavorável pelo emprego de imagens vinculadas ao regime totalitário de Hitler.

Não obstante, a Corte Suprema da Áustria se deparou com idêntica questão quando os mesmos cartazes foram exibidos em território austríaco. Por meio da ação civil pública (no 6 Ob 321/04f) ${ }^{24}$, em 2006 a Corte fundamentou de forma diametralmente oposta: embora a exibição do Holocausto consubstancie em símbolo vinculado ao nazismo e à Shoa, não há associação negativa necessária nisto. A aferição de constitucionalidade da conduta ocorre, pois, que o tema escolhido traz a lume questionamentos fundamentais, porquanto podem ser percebidos como uma

\footnotetext{
21 PETA Deutschland v. Germany, n. 43481/09. nov. 2012.

22 Bundesverfassungsgericht - Beschl. v. 20.02.2009, Az.: 1 BvR 2266/04.

23 Bundesverfassungsgericht - BvR 2620/05.

24 Urteil 6 Ob 321/04f. 12. out. 2006.
} 
contribuição importante para o processo de 'reconciliação com o passado' (Vergangenheitsaufarbeitung).

Como o estandarte da perseguição nazista aos judeus recebeu percepções diametralmente opostas por duas Cortes Constitucionais, em última análise percebese que o mesmo símbolo é interpretado como de valoração axiológica objetiva pela Corte alemã (preponderando a tutela à dignidade das vítimas) e subjetiva pela austríaca (ressaltando o contexto promocional da exibição). Por conseguinte, o fim atingido é estanque ao limite objetivo posto aos símbolos vinculados ao nazismo.

Delfino, Silveira e Castro e Silva (2016) apresentam as várias possibilidades de aproximação valorativa do espectador que se depara com a divulgação de símbolos nazistas: a) favorável, relacionada ao seu conteúdo ideológico, de modo que a comercialização/divulgação cumpre o objetivo de grupos neonazistas, com a realização do programa de disseminação do arquétipo de pensamento nazista; b) desfavorável, relacionada ao seu conteúdo ideológico, e, portanto, a limitação se impõe como meio de evitar a realização dos objetivos discriminatórios; c) favorável (sentido historiográfico promocional), relacionada não ao seu conteúdo, mas ao impacto na História da humanidade. Neste último caso, a divulgação dos símbolos nacional-socialistas adquire um viés crítico e sua divulgação serve para a aquisição de conhecimento filosófico e científico - realização de outro valor positivo - e para evitar a realização dos objetivos discriminatórios ali expostos depois de conhecê-los.

Outro caso importante ocorreu no município de Itajaí, Santa Catarina, no ano de 2014. Dois jovens são processados perante o juízo da $1^{\underline{a}} \operatorname{Vara}$ Criminal$^{25}$ e, conforme narra a denúncia, ambos teriam cometido o delito previsto no artigo 20 da Lei 7.716/1989 por terem veiculado na região central da cidade cartazes em comemoração ao aniversário póstumo de Adolf Hitler. O material continha a gravura do ditador alemão com os dizeres "Heróis não morrem. Parabéns Führer", além de uma cruz céltica com a expressão "White Front" (Frente Branca), mas não a suástica.

O núcleo argumentativo que fundamenta o referido processo é que a apologia ao ditador nazista transmite apreciação axiológica discriminatória de ordem objetiva. Tem-se a apologia hitleriana uma presunção absoluta de equivalência ao ódio e à discriminação - o que, nem sempre, é verdadeiro. Mais uma vez, argumenta-se a impropriedade hermenêutica da abordagem, pois a restrição do uso de símbolos deve

25 Processo $n^{\circ}$ 0008446-59.2014.8.24.0033 (033.14.008446-3). Apelação Penal Pública Procedimento Ordinário. $1^{\text {a }}$ Vara Criminal de Itajaí - SC. Distribuição em 13 de maio de 2014. 
ser pautada na identificação de um discurso de ódio discriminatório e não em uma categoria de símbolos. Na oportunidade, a celebração, ainda que de natureza impopular e controversa de determinadas figuras históricas, a princípio não pode ser equiparada ao antissemitismo, sem a existência de outros elementos que corroborem tal asserção.

Não há necessariamente uma relação finalística entre a apologia dos ditadores nazistas com a promoção do ódio. Essa relação finalística, embora preponderante, não é necessária, de modo que, ao se falar de Hitler o nexo que se estabelece imediatamente é com o nazismo e a Shoa, sem que se exclua a possibilidade de que outros valores estejam atribuídos ao animus do interlocutor. A grande falácia no modelo de criminalização atual repousa justamente nesta rotulação objetiva e seletiva que se dá em face de alguns eventos e figuras históricas em detrimento de outras.

\section{CONSIDERAÇÕES FINAIS}

O discurso de ódio diz respeito à manifestação de ideias que incitam à discriminação odiosa contra determinados grupos, majoritariamente as minorias, ou ofendem suas sensibilidades. A exibição de símbolos com finalidades odiosas, embora seja uma espécie de discurso de ódio, não pode ser pensada como uma entre as demais. Isto porque a inferência da iconografia com o caráter discriminatório não é automática.

Em geral, os símbolos controversos (porquanto fazem alusão à regimes totalitários, grupos de intolerância ou à elementos ofensivos para determinados grupos) demandam uma interpretação conjugada a outros fatores para a aferição de critérios de tolerabilidade. São eles: finalidade, contexto, estilo da exibição, sensibilidade histórico-social em face da simbologia veiculada.

O simbolismo e a iconografia dos regimes totalitários estão intimamente relacionados com a ideologia controversa que tais regimes transferem ao espectador, mas também com os significados do patrimônio cultural específico e da tradição que - embora bastante idiossincráticos - atravessam fronteiras étnicas, nacionais e culturais de uma sociedade específica e adquirem características legais próprias em cada sociedade. Este fato explica as diferentes abordagens legislativas de criminalização que proíbem certos emblemas relacionados com o histórico de 
discriminação mais latente na história local.

O sistema jurídico brasileiro prevê e tipifica delitos relacionados ao ódio sem, contudo, mencionar diretamente essa elementar. Os crimes de discriminação (individual e coletiva), genocídio e divulgação do nazismo são funcionalizados em torno do racismo, em respeito à dignidade humana e ao princípio constitucional da igualdade. Não obstante, no campo do direito penal apenas criminaliza-se a suástica para fins de divulgação do nazismo. Concluiu-se que a legítisca empregada no referido tipo penal é deficiente, visto a ausência de causas que possam excluir a divulgação positiva do referido símbolo (acadêmica, artística, histórica), além do fato de haver indevida limitação no alcance da norma em razão da criminalização expressa e restritiva do "nazismo" e da "suástica". Como resultado, torna-se penalmente irrelevante o fato de o nazismo ser propalado via quaisquer outros meios simbólicos e o fato de que a suástica pode ser utilizada para divulgar outros regimes/grupos de intolerância (neonazismo, K.K.K.). Ademais, verificou-se clara seletividade ao punirse a exibição de símbolos estritamente vinculados ao nacional-socialismo, homiziando-se outras simbologias impactantes nas sensibilidades dos grupos discriminados.

A existência de projetos de lei que visam aprimorar este cenário proporciona o saneamento parcial de tais questões, ampliando-se o rol de símbolos tipificados pela norma (embora ainda atrelados ao aspecto gráfico) e ajustando a epistemologia da norma incriminadora para a subsunção apenas nos casos que a disseminação ocorrer com teor negativo (entenda-se discriminatório).

Em geral, existem outras referências simbólicas, que não as iconográficas, capazes de vilipendiar em idêntica intensidade as sensibilidades dos grupos discriminados. Ademais, nenhum modelo penal deve incorporar a técnica de criminalização objetiva desses símbolos, visto que os receptores podem ter diferentes apreciações críticas em sua veiculação e mesmo esta pode ser feita com várias finalidades - gerando relações próprias entre os direitos e liberdades fundamentais envolvidos. Destarte, o modelo ampliativo, contextual e finalístico parece ser a melhor escolha para a criminalização do discurso de ódio via exposição de símbolos.

\section{REFERÊNCIAS BIBLIOGRÁFICAS}

BRASIL. Projeto de Lei 5358/2016. Altera a redação da Lei no 7.716 , de 5 de janeiro 
de 1989 e da Lei no 13.260, de 16 de março de 2016, para criminalizar a apologia ao comunismo. Câmara dos Deputados. 2016. Disponível em: http://www.camara.gov.br/proposicoesWeb/prop_mostrarintegra;jsessionid=1C79D6 4259BA15EFBD6FA4DA5BA51734. proposicoesWebExterno1 ?codteor $=1460579 \&$ fil ename $=P L+5358 / 2016$. Acesso em: 18 ago. 2017.

BISI, Adriana de Oliveira Gonzaga. (In)justiça de Segurança Nacional: A Criminalização do Comunismo no Brasil Entre 1935-1945. Tese (Doutorado em Direito). Faculdade de Direito de Vitória - FDV. 2017.

COMTE-SPONVILLE, André. Pequeno Tratado das Grandes Virtudes. São Paulo: Martins Fontes, 2009.

DELFINO, Lúcio; SILVEIRA, Marcelo Pichioli da; CASTRO E SILVA, Jhonatan de. Proibição a livro de Adolf Hitler ignora solenemente dispositivos constitucionais. 05. fev. 2016. Consultor Jurídico. Disponível em: http://www.conjur.com.br/2016-fev-05/proibir-livro-adolf-hitler-ignora-dispositivosconstitucionais\#_ednref2>. Acesso em: 01 jun. 2017.

DEUTSCHLAND. Strafgesetzbuch. In der Fassung der Bekanntmachung vom 13.11.1998 (BGBI. I S. 3322). 1998. DeJure. Disponível em: https://dejure.org/gesetze/StGB/86a.html. Acesso em: 18 ago. 2017.

FIJALKOWSKI, Agata. The criminalization of symbols of the past: expression, law and memory. International Journal of Law in Context. v. 10, n. 3, p. 295-314. Cambridge University Press, 2014. Disponível em: http://eprints.lancs.ac.uk/67436/1/_IJC_IJC10_03_S1744552314000135a.pdf. Acesso em: 21 ago. 2017

FORST, Rainer. Os Limites da Tolerância. Tradução Mauro Victoria Soares. Novos Estudos - CEBRAP. n. 84. 2009. São Paulo. SciELO. Disponível em: http://www.scielo.br/scielo.php?script=sci_arttext\&pid=S0101-33002009000200002. Acesso em: 16 ago. 2017.

JACOBS, James B.; POTTER, Kimberly. Hate Crimes: Criminal Law \& Identity Politics. Studies in Crime and Public Policy. Oxford: Oxford University Press, 2000.

MARCHERI, Pedro Lima. Legislação Europeia de Combate ao Nazismo, Doutrinas de Ódio e Discriminação Racial. São Paulo: Editora Cia do Ebook, 2015.

MARCHERI, Pedro Lima. O Nazismo, Neonazismo e Outras Espécies de Discriminação no Sistema Penal Brasileiro. 224 f. Dissertação (Mestrado em Direito) - Centro Universitário Eurípedes de Marília, Fundação Eurípides Soares da Rocha, 2014.

MARCHERI, Pedro Lima; ÁLVARES, Silvio Carlos. A Epistemologia do Racismo no Brasil. Revista de Informação Legislativa do Senado Federal, v. 52, n. 208, p. 149166, out./dez. 2015.

MARCUSE, Herbert. The Essential Marcuse: Selected Writings of Philosopher and 
Social Critic. Beacon Press: Boston, 2007.

NICOLAU, Marcos; ABATH, Daniel; LARANJEIRA, Pablo Cézar; MOSCOSO, Társila; MARINHO, Thiago; NICOLAU, Vitor. Comunicação e Semiótica: visão geral e introdutória à Semiótica de Pierce. Revista Eletrônica Temática. a. 6. n. 8. ago, 2010. Disponível em: http://www.insite.pro.br/2010/agosto/semiotica_peirce_nicolau.pdf. Acesso em: 10 abr. 2016.

PAVITT, William Thomas; PAVITT, Kate. The Book of Talismans, Amulets and Zodiacal Gems. 1992.

PIERCE, Charles Sanders. Semiótica. São Paulo: Editora Perspectiva, 1977.

POPPER, Karl. The Open Society and Its Enemies. v. 1. The Spell of Plato, 1945.

REALE, Miguel. Experiência e Cultura. 2. ed. Campinas: Bookseller, 2000.

ROSENFELD, Michael. Extremist Speech and the Paradox of Tolerance. The Tolerant Society: Freedom of Speech and Extremist Speech in America by Lee C. Bollinger. p. 1457-1481. Harvard Law Review. v. 100. n. 6. abr. 1987.

SANTOS, Christiano Jorge. Crimes de preconceito e de discriminação. 2. ed. São Paulo: Saraiva, 2010.

SILVEIRA, Paulo Fernando. Devido Processo Legal. 2. ed. Belo Horizonte: Del Rey, 1997.

SILVEIRA, Fabiano Augusto Martins. Da Criminalização do Racismo: aspectos jurídicos e sociocriminológicos. Belo Horizonte: Del Rey, 2007.

STEGBAUER, Andreas. The Ban of Right-Wing Extremist Symbols According to Section 86a of the German Criminal Code. German Law Journal. v. 8, n. 2. Disponível

em: https://static1.squarespace.com/static/56330ad3e4b0733dcc0c8495/t/56b862004c2f 858fa5820611/1454924289423/GLJ_Vol_08_No_02_Stegbauer.pdf. Acesso em: 19 ago. 2017.

SVILICIC, Niksa; MALDINI, Pero. Visual Persuasion and Politics: Ideology and Symbols of the Totalitarian Regimes - Case Study: Hammer and Sickle. Antropology. n. 37, v. 2, p. 569-582. 2013.

Recebido em 21/11/2018 Aprovado em 09/06/2019 Received in 21/11/2018

Approved in 09/06/2019 